\title{
Brief Notices / Notices Abrégées
}

Unsigned notices were written by the editors / les notices non signées ont été rédigées par les rédacteurs

Michael Taft, Captured Voices: Five Centuries of Interplay between Folk Literature and Print. An Exhibition for the Bruce Peel Special Collections Library, University of Alberta. I996. [36 pp.] (paper).

Drawing upon items from its own holdings, the Bruce Peel Special Collections Library of the University of Alberta presented between 5 February and 26 April I996 an exhibit entitled Captured Voices: Five Centuries of Interplay between Folk Literature and Print. The label text and a number of visuals from the exhibition appear within this exhibit catalogue of the same name. For the non-specialist, a brief but informative introduction to the interaction of folk literature and print is to be found in the catalogue while specialists no doubt will locate something of particular interest among the eighty-seven items listed. These primarily print items are trans-national in origin and encompass a number of languages, among them English, French, Italian, Swedish, Ukrainian, and Dutch. It is unfortunate that the text of the catalogue is not augmented with more illustrations: those readers who did not have the opportunity to visit the exhibit would benefit from photographs of the books and other print materials that were used in its production.

An illustration of two men singing from broadsides before a crowd serves as the entry point into the catalogue's subject. The interplay between oral and print cultures is addressed initially through a series of speculative questions posed in relation to the illustration. These questions consider the place of purchase of the broadsides, the printer's source to the song (profferred possibilities include the pub, street, fair, and music hall), the level of familiarity of the audience with the song and the possibility of the listeners' knowledge of differing versions, as well as the potential that members of the audience will add the song to their own repertoires or adjust their own versions in light of the printed text. Having raised through these questions some basic considerations around the interaction of oral and print cultures, the exhibit's curator, Michael Taft, then offers an explicit statement on the interplay of the two, in the process also explaining the choice of main title for the exhibit:

Fleeting performances of song, tale, and proverb are caught by the technology of print. These captured voices are then spread far beyond the immediate time and place of their oral performance. The subsequent act of 
reading, reciting or singing these captured voices frees them - influencing others to rewrite, print and publish them once again.... Oral performance and printed texts continually dance the dance, amending each other with each rendition, as they spread literature through space and over time.

While the two might 'dance the dance,' the suggestion of an unequal partnership emerges from the body of the label text. Recurring throughout the catalogue, but never fully addressed, is the indication that greater cultural authority has been vested in print over oral productions. 'No matter that everyone already knew the tale,' the catalogue, for instance, notes in relation to Cinderella, 'print gave the old story an authority it never had before, and printed copies such as this one undoubtedly influenced and changed the local and personal versions of Cinderella.' As the catalogue then adds that in the twentieth century the Disney film has shaped the tale's telling more profoundly than past oral or printed versions of it, one is left to ponder the implications of this third tradition on the reproduction and dissemination of stories and to speculate, in turn, about the relative cultural influence between print and film.

Structurally the exhibit catalogue is divided into four major parts, with subsections appearing within each of the categories. While each major category opens with an introductory paragraph or two of text, each sub-section draws upon items from the library's collection to exemplify its point, with interpretive text appearing in relation to many but not all of the materials noted. The first of the major sections, 'Entertainment and Aesthetics,' places particular focus on the appearance in print of songs, folk narratives (stories, jokes, tall tales), and proverbs, as well as titles for which the folk literature content remains secondary to the books' value as works of visual artistic endeavour. 'Collection and Study,' the second section, considers the scholarly activity around folk literature which has led to its appearance in print 'for the purposes of preservation and study.' Collection in the endeavour of exploring national and ethnic identities, the supernatural, and folk wisdom are highlighted in this category. The spread of religion through song and the presentation of moral teaching and practical wisdom are offered as two examples of folklore collection in the cause of 'Education,' the third section. Finally, the 'Political, Ideological and Social Agendas' for placing folk literature in print are explored in the fourth category, with the items presented offered as evidence of how folk literature has been utilized to promote nationalism, to encourage unity in times of war, and to advocate ideologies, causes and hatred. Brief though it may be, this catalogue on the whole provides a useful sampling of the interplay of folk literature and print.

JANET B. FRISKNEY

Carleton University 
'Every Man his own Doctor': Popular Medicine in Early America. An Exhibition drawn from the Collections of Charles E. Rosenberg, William H. Helfand, and the Library Company of Philadelphia. [Philadelphia]: The Library Company of Philadelphia, 1998. [ii], 64 pp.; \$10.00 U.S. (paper). ISBN 0-9I4076-93-0.

Far from casting off all that relates to books and print, the millennial fever of our electronic age has in many ways served to excite an intense interest in book history and print culture. No longer content even to examine print materials as items of commerce, book historians have joined earlier scholars in exploring the interactions between print and oral cultures and in considering more generally the role of print in popular culture.

Indicative of this latter interest in particular is the exhibition on popular medicine mounted at the Library Company of Philadelphia, the venerable institution begun by Benjamin Franklin in the I730s. Running from April to November 1998, the exhibition presents printed items from the private collections of Charles E. Rosenberg and William H. Helfand together with those held by the Library Company of Philadelphia. As a distinguished historian of medicine, Charles Rosenberg approaches this nineteenth-century material with finesse: he has written authoritatively on medical books for domestic use and on hygiene textbooks for the classroom. William Helfand is a recognized collector of medical ephemera, which he often donates or exhibits in major venues such as the Philadelphia Museum of Art and the National Library of Medicine.

This new exhibition at the Library Company thus marks an impressive collaboration in compiling and interpreting print material published for the popular reader in the United States before 1870 . Rosenberg and Helfand have arranged works by their function (guides to health and advertising vehicles) and then by their main subject or form. 'The Book in the Sickroom' therefore displays substantial publications in domestic and folk medicine; lifestyle; midwifery and nursing; women's medicine and child care; botanic medicine; other sectarian medicine; mental hygiene and phrenology; and finally, sex and birth control. 'Advertising Health to the People' presents more fugitive material: newspapers and magazines; broadsides; books, pamphlets, and almanacs; labels; large broadsides and posters.

The exhibition catalogue does not reproduce the detailed descriptions actually accorded each item in the exhibition; rather, it does something much more valuable in providing complementary essays by the key organizers. After noting in 'The Book in the Sickroom: A Tradition of Print and Practice' that books for personal management of health and disease have a long history, Rosenberg refers to sample publications to show how nineteenth-century America developed 'a new kind of mass market in printed consumables' (p. 5) - one that included a strong demand for medical information. In 'Advertising Health to the People,' Helfand surveys the various media in which promoters hawked their medical wares and services; in so doing, he traces the technical advances that allowed them to dramatize their message through colour illustrations and large broad- 
sides. Both essays are well-illustrated with examples from the collection itself, including several remarkably colourful lithographs and woodcuts. The catalogue then concludes with a checklist of exhibition books and prints prepared by James $\mathrm{N}$. Green of the Library Company. Its value, then, lies not only in capturing a limited event for a wide audience but also in offering a useful synopsis of the myriad forms that popular medical literature took in the United States in this period.

D.C. Greetham and W. Speed Hill, eds. TEXT: An Interdisciplinary Annual of Textual Studies. Vol. 9. Ann Arbor: University of Michigan Press, 1996. X, 492 pp.; $\$ 59.50$ U.S. (cloth). ISBN 0-472-10774-7.

This volume of TEXT, the journal of the Society for Textual Scholarship, is the ninth to appear since I984. Not simply the proceedings of the society's biennial conference, as its editors note in a preface, it stands as an independent annual publication for the study of texts. This issue therefore has changed the subtitle from 'Transactions of the Society for Textual Scholarship' to 'An Interdisciplinary Annual of Textual Studies' to reflect its status more accurately. The third volume to be published by University of Michigan Press, this one also introduces changes in design and editorship; specifically, David Greetham has stepped down as editor. About 150 pages are devoted to seventeen 'Review Essays and Reviews.' Its section on 'Essays and Studies' contains sixteen articles that open with Bruce Metzger's presidential address on 'Some Curious Bibles' and range from Jerome McGann on the rationale of hypertext and Deirdre Phillips on the text in the development of literary sociology to studies of texts in literature, art and music from the Anglo-Norman to modern-day periods. In addition, a set of four essays on 'Teaching Textual Criticism' emphasizes the need to instill in the literary classroom a 'user-friendly form of textual scholarship' (p. 137), as Philip Cohen states in his introductory essay. Then George Bornstein offers concrete ways in which exercises and readings may be 'smuggled into' (p. I48) the undergraduate literary curriculum. David Holdeman and Hans Walter Gabler comment on Bornstein's approach while describing their own new courses designed to integrate textual with literary criticism.

Pierre-Marc De Biasi et Marc Guillaume, coord. Pouvoirs du papier. Numéro thématique des Cahiers de médiologie, no 4, deuxième trimestre I997. 350 p.; 6oFF (broché). ISBN 2-07-075029-9.

La vogue irrésistible qui porte aux nues les nouvelles technologies de l'information et de la communication (NTIC), depuis moins d'une décennie, n'a pu faire 
l'économie d'un pathos du livre et du papier. Aux chantres du cybervillage, à la prophétie facile, annonçant la substitution imminente du papier par l'écran comme support de médiation de l'information et du savoir, ont répondu, tout aussi nombreux, les inconsolables nostalgiques de la fibre naturelle. La remise en cause de cette fonction dominante du papier, qui lui valu de s'imposer à partir du $\mathrm{XII}^{\mathrm{e}}$ siècle comme principal support de communication écrite en Occident, a favorisé l'éclosion de nouvelles analyses rétrospectives à son sujet. Autrefois parent pauvre de la recherche sur la culture écrite - exception faite des études codicologiques des médiévistes - l'étude du papier, de ses usages, de sa production matérielle et de ses significations sociales, suscite désormais un intérêt accru. À preuve, ce dernier numéro des Cahiers de médiologie. Partant du principe que le papier est un "élément médiateur de culture" autour duquel s'articule ce que les coordonateurs du volume appellent la "graphosphère occidentale moderne", autrement dit l'univers de la res scriptura, les différents collaborateurs s'interrogent sur les diverses fonctions de médiation du papier dans l'histoire des idées et des sociétés. Ce matériau, dont la production industrielle occupe encore aujourd'hui une part importante de l'activité industrielle mondiale $2,5 \%$, soit la même part que l'industrie aéronautique), entretient avec la mémoire, le savoir, l'art, la croyance et le pouvoir, des rapports qui restent à éclaircir. À travers des entretiens avec des individus concernés de près ou de loin par le papier (le philosophe J. Derrida, un ingénieur forestier, le directeur de la fabrication des livres chez Gallimard, un spécialiste de la restauration des documents graphiques, le gouverneur de la Banque de France et deux experts scientifiques auprès des tribunaux) et des articles de chercheurs venant de différents horizons, Pouvoirs $d u$ papier renouvelle le questionnaire et témoigne magnifiquement des multiples enjeux de la production et des usages de ce "chiffon savant». L'histoire de l'invention et du développement de la production papetière, la menace que fait peser sur la conservation du patrimoine écrit l'acidité du papier fabriqué de pulpe de bois et celle que fait peser ce mode de fabrication sur l'écosystème planétaire, la lutte que se livre le silicium des puces informatiques, le plastique, le papier et les métaux précieux sur le marché de la crédibilité monétaire, les identités de papier et l'avenir de l'édition traditionnelle sont autant d'aspects abordés.

David L. Vander Meulen, ed. Studies in Bibliography. Vol. 50. Charlottesville, Va.: Bibliographical Society of the University of Virginia, I997. 4I 6 p.; \$40 U.S. ISBN 0-8I39-I73 I-X.

In 1997 the Bibliographical Society of the University of Virginia celebrated its fiftieth anniversary. To mark this occasion, Studies in Bibliography has published an expanded issue, featuring a history of the Society and its publications, in addition to a full complement of articles.

David L. Vander Meulen, current editor of Studies, presents a detailed and interesting history of the Society. The lectures sponsored by the Society, the exhibitions, 
the prizes awarded to Virginia printers and to University of Virginia student book collectors, have been local initiatives. But the Society's membership has always been international, and the influence of its publications undeniably so. Vander Meulen appends a bibliography of Society publications (some 285 items), along with a personal name index. He also includes reproductions of significant Society documents and photographs of prominent council members. Among the photographs is a charming snapshot of Fredson Bowers in his orchard, flanked by two children whose arms overflow with daffodils.

Of all the Society's publications, none has enjoyed greater international influence than Studies in Bibliography. G. Thomas Tanselle, the most frequent and lengthy contributor to Studies, traces the development of the journal and emphasizes the importance of Fredson Bowers' editorship. A tireless and meticulous editor, Bowers continually sought out worthy contributions for Studies, encouraging both established scholars and promising students to submit their work. Though focussing on analytical bibliography, the journal published bibliographical work on any genre and time-period, and researchers from all countries were invited to contribute. Bowers welcomed lengthy articles, as long as their quality was high, and he readily published opinions with which he did not agree, if the author's scholarship was sound. Tanselle quotes numerous contributors who were grateful and flattered by the detailed, sympathetic attention that their articles received at Bowers' hands. And he mentions others, no less pleased, who were amazed to see their ideas clarified and extended in ways they had not dreamed possible.

David Vander Meulen, who shared editorial duties with Bowers for eight years, became sole editor of Studies in Bibliography after Bowers' death in I991. Under his direction, the journal has become available on the World Wide Web - an extraordinarily generous initiative. To accompany Tanselle's account, David L. Gants and Elizabeth K. Lynch have prepared an author index to Studies.

These two articles, with their accompanying bibliographies and indexes, form an interesting and valuable account of the Society and journal that have shaped the course of analytical bibliography over the last fifty years.

ELAINE HOAG

National Library of Canada

Anne-Marie Chartier et Suzanne Pouliot, dir. Discours institutionnels sur la lecture des jeunes: perspectives diachroniques. Numéro thématique des Cahiers de la recherche en éducation, vol. 3, no. 3, I996. I66 p. (broché). ISSN I I95-5732.

L'accès au livre n'est pas un geste neutre. De tout temps, cette pratique culturelle singulière s'est vu borner par des instances sociales qui cherchent à en définir les modalités. La lecture suppose un apprentissage qui implique autant l'assimilation d'un code graphique, l'alphabet, que celui d'un code social qui en garantit la 
recevabilité. C'est à la définition et à la diffusion de ces normes de recevabilité que s'intéressent les contributions regroupées par A.-M. Chartier et S. Pouliot. D'abord préoccupées par la situation québécoise, Discours institutionnels sur la lecture des jeunes s'accompagne d'un dialogue fécond avec les travaux de chercheurs français (A.-M. Chartier, I. Havelange et J. Verrier). Plongeant une première sonde d'observation au coeur des écoles de la Nouvelle-France, il propose un voyage diachronique à travers les discours tenus par des prescripteurs de toutes sortes (clergé, intervenants scolaires, bibliothécaires, éditeurs), s'immisçant à différentes étapes et de façons contrastées dans le processus de lecture. Deux lignes de force émergent de ce collectif dont l'unité intellectuelle, trop rarement présente dans ce genre d'entreprise éditoriale, facilite l'observation. Premièrement, la persistance, du XviI ${ }^{\mathrm{e}}$ siècle à $\mathrm{I} 960$, de la domination $\mathrm{d}^{\prime} \mathrm{un}$ modèle catholique de lecture de formation au sein duquel régnait un régime dichotomique du bon et du mauvais livre, d'abord organisé autour de la notion de morale puis autour du caractère instructif. Deuxièmement, le renversement progressif, en cours de $\mathrm{xx}^{\mathrm{e}}$ siècle, $\mathrm{d}^{\prime}$ un discours restrictif appelant à la modération (lire lentement un petit nombre de livres triés sur le volet) vers un discours incitatif faisant la promotion d'un "plaisir de lire" capable de contrer une désaffection des jeunes diagnostiquée par les professionnels de la lecture. Que ce soit à travers l'analyse de règlements épiscopaux ou scolaires, de manuels scolaires, d'articles de journaux ou de revues et des publications destinées à la jeunesse, ce numéro thématique montre la richesse de ce champ d'investigation.

Joseph L. Peyser, ed. and transl. Letters from New France. The Upper Country, I686-I783. Urbana/Chicago: University of Illinois Press, I992. 248 p.; 34,95 \$ U.S. (cloth). ISBN 0-252-OI853-2.

Contrairement à ce que le titre laisse présager, il ne s'agit pas ici d'une édition critique de lettres missives d'ordre personnel, commercial ou administratif concernant les "pays d'en haut", au cours du Régime français. En fait, letters est à prendre dans son sens le plus large. La correspondance n'occupe aucune place distinctive dans cet ouvrage et se fond avec d'autres documents tels que des rapports administratifs, des journaux de campagne, des ordonnances royales, des mémoires de fournitures pour les forts, voire même de larges extraits d'articles de l'auteur paru précédemment (voir notamment aux pages 7 I suiv., 78 suiv., I 23 suiv. et 136 suiv.). Ainsi, bien que proche par son intérêt thématique, Letters from New France a peu en commun avec l'entreprise d'édition d'une partie des papiers Contrecoeur, menée par Fernand Grenier aux Presses de l'Université Laval, en 1952. En réalité, la publication de J.L. Peyser se rapproche davantage d'une histoire par le texte que d'une véritable édition critique de documents. Elle s'inspire largement des travaux effectués par ce professeur de français à l'Indiana University at South Bend pour le compte de la ville de Niles dans le Michigan, où s'élevait anciennement le fort Saint-Joseph, pivot de la présence française dans 
la vallée de l'Ohio. D'ailleurs, l'intérêt principal de cet ouvrage réside avant tout dans la mise à la disposition du public américain, en traduction anglaise, de documents français qui lui étaient jusque-là inconnus. Ces documents, puisés essentiellement au Fonds des colonies des Archives nationales de France (séries $\mathrm{B}, \mathrm{B}^{\mathrm{I}}, \mathrm{C}^{\mathrm{II}} \mathrm{A}, \mathrm{C}^{\mathrm{II} \mathrm{E}}, \mathrm{C}^{13}, \mathrm{~F}^{2}, \mathrm{~F}^{3}$ ) servent à illustrer les propos de l'auteur. Ils y occupent une place tellement marginale qu'ils sont exclus d'une table des matières pourtant finement découpée, mais organisée autour de titres thématiques. De plus, ils ne font l'objet d'aucune liste. Par conséquent, il n'existe aucun moyen de retrouver rapidement un des documents publiés. 